\title{
Reprocessability of PHB in extrusion: ATR-FTIR, tensile tests and thermal studies
}

\author{
Leonardo Fábio Rivas ${ }^{1}$, Suzan Aline Casarin², Neymara Cavalcante Nepomuceno ${ }^{3}$, Marie Isabele Alencar ${ }^{1}$, \\ José Augusto Marcondes Agnelli², Eliton Souto de Medeiros ${ }^{3}$, Alcides de Oliveira Wanderley Neto ${ }^{4}$, \\ Maurício Pinheiro de Oliveira ${ }^{5}$, Antônio Marcos de Medeiros ${ }^{1}$ and Amélia Severino Ferreira e Santos ${ }^{3 *}$
}
'Department of Materials Engineering - DEMat, Universidade Federal do Rio Grande do Norte - UFRN, Natal, RN, Brazil

${ }^{2}$ Department of Materials Engineering - DEMa, Universidade Federal de São Carlos - UFSCar, São Carlos, SP, Brazil

${ }^{3}$ Department of Materials Engineering - DEMAT, Universidade Federal da Paraíba - UFPB, João Pessoa, PB, Brazil

${ }^{4}$ Department of Chemistry - DQ, Universidade Federal do Rio Grande do Norte - UFRN, Natal, RN, Brazil

${ }^{5}$ Institute of Science and Technology - ICT, Universidade Federal de São Paulo - UNIFESP,

São José dos Campos, SP, Brazil

*amelia@ct.ufpb.br

\begin{abstract}
Mechanical recycling of biodegradable plastics has to be encouraged, since the consumption of energy and raw materials can be reduced towards a sustainable development in plastics materials. In this study, the evolution of thermal and mechanical properties, as well as structural changes of poly(hydroxybutyrate) (PHB) up to three extrusion cycles were investigated. Results indicated a significant reduction in mechanical properties already at the second extrusion cycle, with a reduction above $50 \%$ in the third cycle. An increase in the crystallinity index was observed due to chemicrystallization process during degradation by chain scission. On the other hand, significant changes in the chemical structure or in thermal stability of PHB cannot be detected by Fourier transform infrared spectroscopy (FTIR) and thermogravimetric analyses (TGA), respectively.
\end{abstract}

Keywords: biopolymer, degradation, PHB, recycling, reprocessing.

\section{Introduction}

The rate of municipal solid waste (MSW) generation is rising more than the rate of urbanization around the world ${ }^{[1]}$. By 2025, the volume of MSW generated worldwide is expected to double, reaching an amount of 2.2 billion tonnes per year ${ }^{[1]}$. In general, plastics are of main concern because they represent between 3 and $14.3 \mathrm{wt} \%$ of the total MSW, most are from non-renewable sources and have relatively low recycling rates ${ }^{[1-3]}$.

A key practice to minimizing the environmental problems associated with solid waste is the practice of the 3R (Reduce, Reuse and Recycle) concept, which contributes to reduce energy and natural resources consumption, extend life cycle of products and landfills, and store carbon for a longer period, all important initiatives within the concept of sustainable development. Another alternative that has gained importance is the replacement of petroleum-based plastics by biopolymers from renewable resources, which are generally compostable and able to close the carbon cycle. According to the European Union Regulation, composting is a considered and accepted way of recovering biodegradable packaging wastes ${ }^{[3]}$. However, recycling of biopolymers can be an alternative to composting and to reduce carbon dioxide emission, thus meeting the $3 \mathrm{R}$ concept. This approach not only saves energy that would be used in polymer synthesis, but also reduces costs associated with bioresources (monomers) used to produce new bioplastics and spares carbon resources. Since biopolymers are commonly used in the production of short-life goods, recycling of these polymers becomes even more important because of the large amount of waste generated in markets, as well as insumes consumed.

Nevertheless, in the case of biodegradable plastics, there are few studies related to their recycling ${ }^{[4-7]}$. Life cycle analysis ${ }^{[8]}$ of poly(lactic acid) (PLA), which is one the most studied biopolymers, pointed out that despite of its low environmental impacts, this situation can worsen if recycling is not achieved. According to Shah et al. ${ }^{[9]}$, pyrolysis, solvolysis and enzymatic monomer recycling are the most promising feedstock recycling technologies for biodegradable plastics because most biopolymers have heteroatoms in their main chain, which reduce thermal stability and increase susceptibility to hydrolysis. Besides that, studies of biopolymers recyclability by multiple reprocessing are also important due to the fact that the production of biopolymer-based products may involve more than one extrusion step and mechanical recycling is the most energy efficient recycling technology.

Polyhydroxyalcanoates (PHAs) have attracted a great deal of attention due to their types, properties similar to conventional plastics, biodegradability, biocompatibility, renewability, and synthesis by biotechnological processes ${ }^{[10,11]}$. Although their discovery occurred early, PHAs were rediscovered in the $1980 \mathrm{~s}$, and their use has gained increasing attraction, particularly in the last decades, as a 
consequence of the reduction and limitation of the fossil fuel resources, allied with the increasing concern about the environmental issues caused by improper manipulation, use and disposal of such non-renewable materials. Among these polymers, biosynthesized polyhydroxybutyrate (PHB), the most common PHA, has a high potential to compete with commodity polymers due to its similarity in crystallinity, melting temperature, tensile strength and Young's modulus, and competitive costs ${ }^{[12]}$. Nevertheless, high stiffness, brittleness and poor thermal stability above the melting temperature (a narrow processability window) are some of its drawbacks compared to many conventional polymers ${ }^{[13-15]}$.

Feedstock recycling of PHB has already been considered as a viable route to produce end products such as crotonic acid, linear oligomers having crotonate end groups and a cyclic trimer, as well as to produce plasticized PLA by reactive extrusion grafting of PHB degradation products onto PLA chains ${ }^{[16-19]}$. At temperatures a little above the melting point, there is a rapid decrease in molecular weight and a subsequent production of crotonic acid as the main volatile product ${ }^{[20-23]}$. The presence of moisture, fermentation residues, oxygen, metal and alkali catalysts also is known to favor thermal degradation ${ }^{[14,24-28]}$. This is an important limitation for processing and consequently, to mechanical recycling. Therefore, there has been a great deal of interest in studying the thermal degradation behavior of PHB and other related poly(hydroxyalkanoate) $\mathrm{s}^{[29-35]}$. Also studies seeking to improve the thermal stability of PHB by grafting chemicals in PHB chain ${ }^{[33,36]}$, and adding polymeric additives in PHB matrix ${ }^{[37,38]}$ have been developed.

The thermal degradation behavior of PHB has been discussed in many works ${ }^{[14,20,21,30,39-42]}$, in which a random chain scission reaction ( $\beta$-elimination) involving a six-membered ring transition state (Figure 1) has been considered as the main mechanism based on typical structures of pyrolysis products, i.e., crotonic acid and oligomers with a crotonate end group, i. e., unsaturated end groups. Since the proposed mechanism is a non-radical random chain scission the conventional stabilizers and antioxidant was not efficient to prevent PHB degradation ${ }^{[38]}$.

In this work, the effect of multiple reprocessing cycles on the properties of PHB products obtained by more than one reprocessing cycle, as well as in their recyclability was evaluated. Thermal and mechanical properties were measured after each extrusion cycle, and correlated with polymer structural changes.

\section{Materials and Methods}

\subsection{Materials}

Poly(3-hydroxybutyrate) (PHB) powder, produced by bacterial fermentation, was kindly supplied by PHB Industrial S/A, Serrana-SP, Brazil, registered under the brand BIOCYCLE ${ }^{\circledR}$ and used as received. This polymer has a melt flow index of $6.5 \mathrm{~g} / 10 \mathrm{~min}\left(190^{\circ} \mathrm{C}, 2.16 \mathrm{~kg}\right)$ and number-average molecular weight (Mn) of 56,650 g. $\mathrm{mol}^{-1}$, weight-average molecular weight (Mw) of 167,223 g.mol ${ }^{-1}$, and polydispersity index (PDI) of 2.95, as measured by gel permeation chromatography.

\subsection{Reprocessing cycles}

Extrusions were carried out using an AX Plásticos (São Paulo, Brazil) single screw extruder $(\phi=16 \mathrm{~mm}$, $\mathrm{L} / \mathrm{D}=26$ and $90 \mathrm{rpm}$ ) with Maddock mixing section between the compression zone and the flow control zone up to three times. Temperature profile used was: 165, 170 and $170{ }^{\circ} \mathrm{C}$. The neat PHB powder (virgin polymer) or pellets (extruded polymer) was dried at $60^{\circ} \mathrm{C}$ under vacuum for $12 \mathrm{~h}$ before each processing cycle. Since it is a first approach on recyclability of $\mathrm{PHB}$, no other materials/additives, such as nucleating agent or plasticizers, were used.

\subsection{Compression molding}

Compression molded films were prepared in a hydraulic press (capacity of $24 \mathrm{kgf}$ ) at $170{ }^{\circ} \mathrm{C}$ for $1 \mathrm{~min}$ at about $10 \mathrm{kgf}$, followed by quenching in an ice-water bath.

\subsection{Mechanical properties}

Tensile tests were carried out according to ASTM D 882 at $25^{\circ} \mathrm{C}$ and strain rate of $1 \% \cdot \mathrm{min}^{-1}$ using a TA Instruments DMA, Q800. The test-specimens with dimensions around $(50 \times 10 \times 0.075) \mathrm{mm}$ were cut from films prepared by compression molding. At least 5 samples were carried out for virgin PHB and after each extrusion cycle. Results were averaged arithmetically.

\subsection{Fourier transform infrared (FTIR) spectroscopy}

Infrared spectra were obtained by a Nexus 470 Nicolet FTIR spectrophotometer. 32 scans, resolution of $4 \mathrm{~cm}^{-1}$ and interval of $2 \mathrm{~cm}^{-1}$ were used. Analyses were performed in the attenuated total reflectance mode (ATR) by direct analysis of films on SnZn crystal.

\subsection{Thermogravimetric analysis (TGA)}

Thermogravimetric analyses (TGA) were conducted under $50 \mathrm{~mL} \cdot \mathrm{min}^{-1}$ of nitrogen flow, using a Shimadzu TGA 60 apparatus. The samples were heated to $600{ }^{\circ} \mathrm{C}$ at $20{ }^{\circ} \mathrm{C} \cdot \mathrm{min}^{-1}$. The characteristic degradation temperatures: temperature at the maximum of the DTG curve (Tmax) and the temperature $(\mathrm{Tx} \%)$ at which the sample loses $\mathrm{x} \%$ of its initial weight were determined.

\subsection{Differential scanning calorimetry (DSC)}

Thermograms were obtained using a Shimadzu DSC 60 differential scanning calorimeter (DSC). Calibration was performed with indium and tin in the temperature range from 0 to $350{ }^{\circ} \mathrm{C}$. The sample weight was approximately

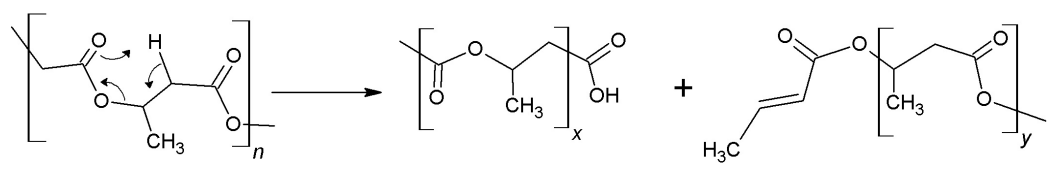

Figure 1. PHB random chain scission mechanism. 
6-10 mg. All the samples were heated from $25^{\circ} \mathrm{C}$ to $220^{\circ} \mathrm{C}$ at $10^{\circ} \mathrm{C} . \mathrm{min}^{-1}$ in purge flow of nitrogen at $50 \mathrm{~mL} / \mathrm{min}$. Melting enthalpies were determined using constant integration limits. The degree of crystallinity (Xc) was determined using the following equation:

$$
X c(\%)=\frac{\Delta H m}{\Delta H_{100 \%}} x 100
$$

where: $\Delta \mathrm{Hm}$ is the melting enthalpy per unit of weight of PHB samples and $\Delta \mathrm{H}_{100 \%}$ denotes enthalpy per unit weight of the $100 \%$ crystalline $\mathrm{PHB}$, which is assumed to be $146 \mathrm{~J} / \mathrm{g}^{[43]}$. All DSC analysis was taken from the films obtained by compression molding in order to best represent the material undergoing mechanical test. This procedure has been already adopted by Srubar et al. ${ }^{[44]}$.

\section{Results and Discussions}

\subsection{Mechanical properties}

In order to assess the industrial possibility of PHB recycling, its mechanical properties must stay as stable as possible along the processing cycles. A representative tensile curve of virgin PHB was depicted in Figure 2, which shows its brittle nature. Therefore, in this case, the tensile strength is coincident with tensile stress at break. Figure 3 shows the values of tensile strength of PHB, before and after each extrusion cycle. It can be observed that the tensile stress at break decreased from 32.1 MPa to $13.4 \mathrm{MPa}$ after three extrusion cycles. At the $3^{\text {rd }}$ cycle, the tensile stress at break had the same order of magnitude of the tensile strength of $\mathrm{LDPE}^{[45]}$. However, the elongation at break of these two polymers is very distinct and the tactile sensation of PHB at the $3^{\text {rd }}$ cycle is like a brittle material, which hindered additional extrusion cycles for further characterization of samples.

According to Pillin et al. ${ }^{[5]}$, a similar decrease in tensile strength values was observed only at the $6^{\text {th }}$ injection cycle for PLA. Nevertheless, the properties of PLA stay useful,

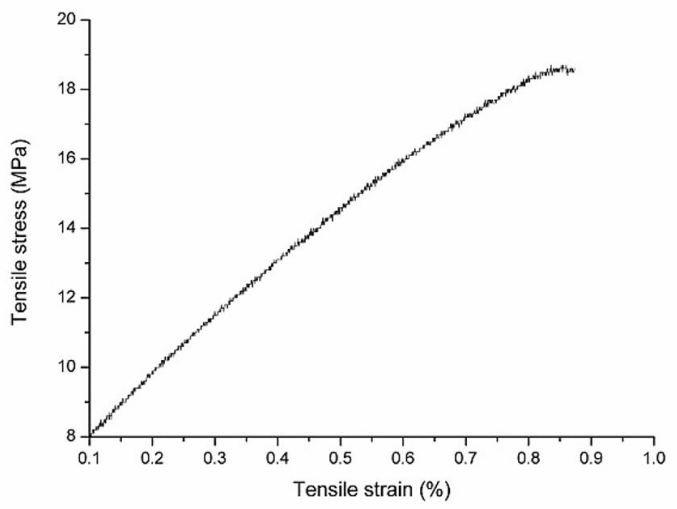

Figure 2. Representative tensile stress-strain curve of virgin PHB determined at $1 \mathrm{~mm} \cdot \mathrm{min}^{-1}$ by using a universal machine Shimadzu AG-X 10kN model, based on the ISO standard 527- 2. The test-specimens, type $5 \mathrm{~B}$, were prepared by laser cutting from films prepared by compression molding. i.e., above about $10 \mathrm{MPa}$, until the $7^{\text {th }}$ cycle, the maximum number of cycles evaluated.

The color change of PHB from an off-white powder to opaque brown color was observed after first extrusion, as reported in the literature ${ }^{[46,47]}$. Such behavior is accounted for PHB chromophoric carbonyl groups.

The strong decrease in tensile strength is probably ascribed to a reduction in the molecular weight of PHB due to chain scission reactions caused by thermal degradation ${ }^{[15,20,31]}$ during extrusion cycles. It is well established that the former properties are strongly affected by chain scission, since the broken chains are confined in the amorphous regions between the lamellae, where tie molecules, which are responsible for the mechanical integrity of semicrystalline polymers, are located ${ }^{[48]}$

The hypothesis of mechanical properties decrease with molecular weight was in good agreement with the results achieved by Sadi et al. ${ }^{[47]}$ and Renstad et al. ${ }^{[49]}$. In both works, the tensile strength at break for PHB and (poly-3-hydroxy butyrate-co-valerate) (PHBV), respectively, decreased with molecular weight depression. Nevertheless, none of these studies have determined until how many extrusion cycles the mechanical properties of PHB still useful and the rate that decay in the mechanical properties with extrusion cycles occurs. Kendall ${ }^{[50]}$, for example, in its life cycle assessment for the production of PHB from material recovery facilities considers that there is no current technology for PHB mechanical recycling, but in this study results show that it is possible to recycle PHB up to three extrusion cycles without any additive to inhibit its degradation or improve its properties. For conventional plastics, it is known that during thermomechanical recycling ${ }^{[51-53]}$, mechanical properties decrease with increasing multiple extrusion or injection molding cycles. This trend depends upon the type and chemical nature of the polymer. Nevertheless, blends of recycled polymers with virgin ones, reprocessing with stabilizers and incorporation of reinforcing fillers are alternatives to improve recycled plastics properties ${ }^{[54-57]}$.

Furthermore, changes in mechanical properties could be also attributed to changes in the structure and stability of crystalline state or rearrangement of interlamellar amorphous state ${ }^{[44,58-60]}$. Nevertheless, changes in molecular weight or crystalline and amorphous morphologies are beyond the scope of this study.

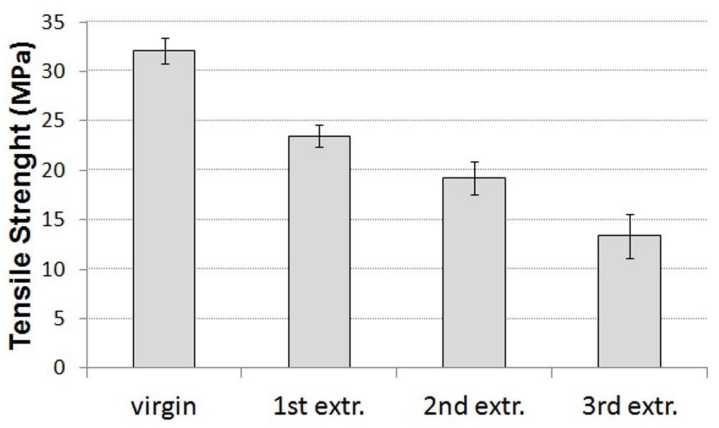

Figure 3. Results of tensile strength for PHB before and after each extrusion cycle. 


\subsection{Fourier transform infrared (FTIR) spectroscopy}

The original chemical structure of PHB consists of molecules terminated by a hydroxyl and a carboxyl group. The hydroxyl and carboxyl end groups are observed at approximately $3600 \mathrm{~cm}^{-1}$ and $1720 \mathrm{~cm}^{-1}$, respectively. Other characteristics PHB vibrations appear at around $1277 \mathrm{~cm}^{-1}$ and $970 \mathrm{~cm}^{-1}$. The peak at $1277 \mathrm{~cm}^{-1}$ denotes the $-\mathrm{C}-\mathrm{O}-\mathrm{C}$ - group and at $970 \mathrm{~cm}^{-1}$ is assigned to bending vibrations of olefinc $-\mathrm{C}-\mathrm{H}^{[61,62]}$.

As the thermal degradation proceeds, it incorporates vinyl (crotonate) ester and carboxyl groups end groups in PHB structure ${ }^{[20,30,31,41]}$. Therefore, a gradual increase in crotonate ester groups with extrusions paths can be expected, as well as a decrease in hydroxyl groups present in the original polymer. The absorption band assigned to stretching vibrations of double carbon/carbon bond, $-\mathrm{C}=\mathrm{C}$-, is expected to appear at around $1660 \mathrm{~cm}^{-1[63]}$.

FTIR analyses of PHB samples during extrusion cycles are shown in Figure 4, which presents the spectra of virgin PHB and PHB after each extrusion cycle.

The presence of absorption bands associated to the formation of new chemical groups due to degradation mechanisms of polymer was not noticed. According to Yu et al. ${ }^{[64]}$, the band at $1700-1720 \mathrm{~cm}^{-1}$, assigned to the carbonyl absorption band in the infrared spectra, is shifted to $1654 \mathrm{~cm}^{-1}$ when conjugated with vinyl end groups. Nevertheless, no shift can be observed for this band (Figure 5), corroborating the results of Yu et al. ${ }^{[44]}$ that observed no difference in infrared absorption of PHB film surface even after up to $40 \mathrm{wt} \%$ of the PHB film submitted to alkaline hydrolysis had been decomposed into crotonic acid and 3-hydrobutyric acid. In relation to the intensity of absorption band at $1720 \mathrm{~cm}^{-1}$, nothing can be commented, since absorption intensity in ATR/FTIR spectroscopy depends largely on the quality of contact between sample and crystal ${ }^{[65]}$.

\subsection{Thermogravimetric analysis (TGA)}

Table 1 shows the values of temperature at the peak of the DTG curve (Tmax) and the temperature at which the sample loss $10 \%$ of its initial weight $\left(\mathrm{T}_{10 \%}\right)$. A peak on a DTG curve characterizes the temperature at the highest rate of thermal degradation. Figure 6 depict the TGA curves of $\mathrm{PHB}$ before and after multiple extrusion cycles.

According to the literature ${ }^{[20,30,31,41]}$, as PHB degradation proceeds, an ester chain with an unsaturated ester as end group, and an ester chain with a carboxylic acid as end group are formed. Each of these two types of ester may react at a distinct rate. However, $\mathrm{COOH}$ and $\mathrm{COOR}$ groups have very similar inductive effects ${ }^{[66]}$, such that any structural changes suffered by PHB during extrusion cycles were not enough to change the thermal behavior of PHB. The TGA curves are all superposed and only a slight shift between them at the beginning of the curve could be verified (Figure 6).

No mass loss was observed until about $225^{\circ} \mathrm{C}$ and the temperature at DTG peak (Tmax) was about $300{ }^{\circ} \mathrm{C}$. The thermal decomposition of PHB takes place within a narrow temperature range, i. e., $235 \sim 315^{\circ} \mathrm{C}$. For all samples, the residual weight is lower than $0.5 \mathrm{wt} \%$. Each TGA curve indicates a single step degradation, which means that the

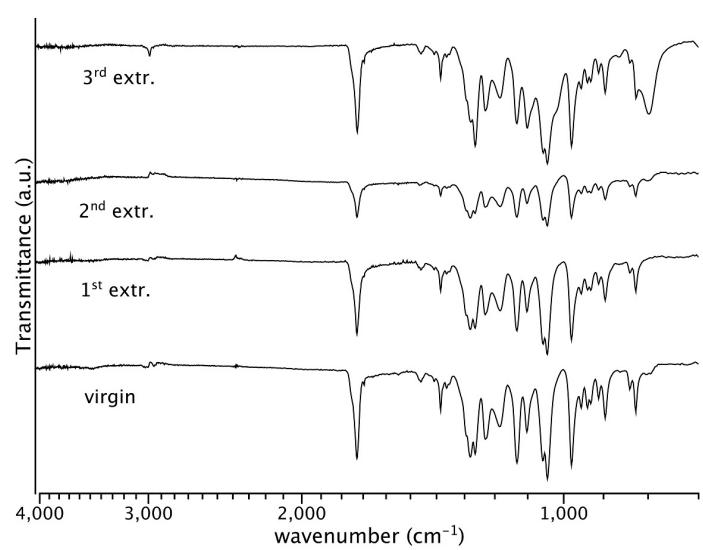

Figure 4. FTIR spectra of PHB as a function of each extrusion cycle.

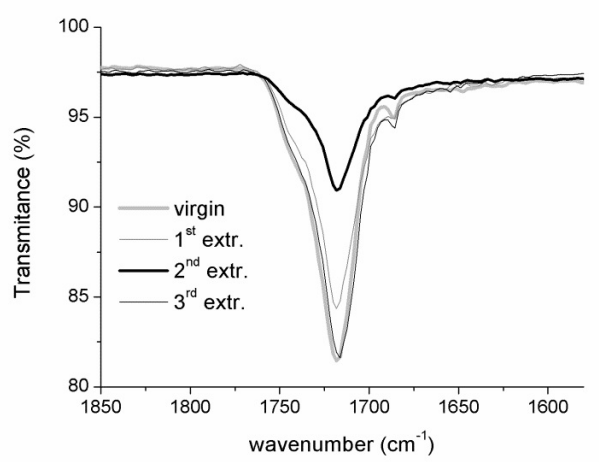

Figure 5. FTIR spectra in stretching region of $-\mathrm{C}=\mathrm{O}$ of $\mathrm{PHB}$ before and after each extrusion cycle.

Table 1. Temperature data from TGA curves of virgin and reprocessed $\mathrm{PHB}$.

\begin{tabular}{ccc}
\hline Extrusion cycle & $\mathbf{T}_{10 \%}\left({ }^{\circ} \mathbf{C}\right)^{*}$ & Tmax $\left({ }^{\circ} \mathbf{C}\right)^{* *}$ \\
\hline 0 & 271.0 & 297.2 \\
$1^{\text {st }}$ & 271.0 & 297.1 \\
$2^{\text {nd }}$ & 271.1 & 299.5 \\
$3^{\text {rd }}$ & 270.7 & 297.4 \\
\hline
\end{tabular}

*T10\% - temperature at $10 \mathrm{wt} \%$ of weight loss; **Tmax - temperature at the inflection point of the peak of DTG curve.

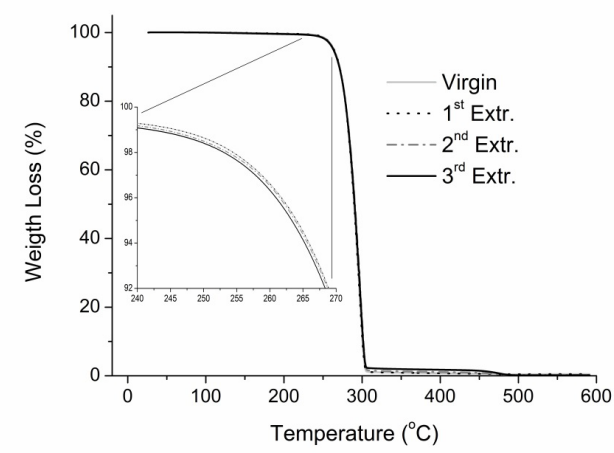

Figure 6. Thermogravimetric curves of PHB as a function of extrusion cycles. 
Table 2. Thermal properties of PHB as a function of extrusion cycles.

\begin{tabular}{ccc}
\hline Extrusion cycle & $\mathbf{X c}(\%)$ & $\mathbf{T m}\left({ }^{\circ} \mathbf{C}\right)$ \\
\hline 0 & 57.7 & 174 \\
$1^{\text {st }}$ & 58.8 & 172 \\
$2^{\text {nd }}$ & 62.7 & 172 \\
$3^{\text {rd }}$ & 62.2 & 172 \\
\hline
\end{tabular}

thermal degradation of PHB polymer chains occurs by only one mechanism ${ }^{[39]}$.

\subsection{Differential scanning calorimetry (DSC)}

The results of the crystallinity degree (Xc) and melting temperature (Tm) are shown in Table 2.

According to these results, the crystallinity degree increased from 57.7 to $62.2 \%$, this increase was more noticeable from the first to the second extrusion cycle. This evolution of the crystallinity with the number of extrusion cycles is also likely to be ascribed to a gradual decrease of the molecular weight of PHB which enhances the mobility and increases crystallization during the cooling step. This phenomenon is also known as chemicrystallization process ${ }^{[47]}$. Corroborating with this hypothesis, there is the tensile strength results that conversely decreased with extrusion cycles, indicating that the increase in crystallinity does not occur with the increase of tie molecules, responsible for transferring stress between two crystalline lamellae. The same behavior was observed for PLA at multiple injections cycle ${ }^{[5]}$. Furthermore, contributions of physical processes related to constraints imposed by amorphous chains ${ }^{[60]}$ due to progressive crystallization process of PHB can be disregarded because each measurement was carried out at the same aging time.

The melting temperature decreases slightly at the first extrusion cycle and remains constant for further extrusion cycles. This modification in melting temperature reflects the formation of less perfect crystalline regions, which corroborates with the possibility of molecular weight reduction $^{[25]}$

\section{Conclusions}

Along multiple extrusion cycles, PHB suffered several changes such as, decrease in mechanical properties and increase in the degree of crystallinity. According to these results, a loss in tensile strength at break of PHB above $50 \%$ was observed at the third extrusion cycle. Nevertheless, that decrement in mechanical properties was significant at the secord cycle, i.e., $\sim 40 \%$. Also an increase in crystallinity degree was noticed mainly from the first to the second extrusion cycle, which probably could be associated to chemicrystallization process. FTIR results did not show any significant changes in polymeric structures associated to the formation of new chemical groups. Similarly, the thermal stability of PHB along processing cycles exhibited only a trend to decrease the thermal stability with extrusions paths, as evidenced by TGA curves. It is worth to note that the recyclability potential explored in this work refers to property retention up to three extrusion cycles under extreme recycling conditions $(100 \%$ recycling with no added virgin polymer and no additive or reinforcement). Therefore, improvement in $\mathrm{PHB}$ recyclability can be achieved by mixtures with virgin PHB, or incorporation of stabilizers and/or chain extenders to control its degradation during reprocessing.

\section{Acknowledgements}

The authors gratefully acknowledge to PHB Industrial S.A. for PHB providing the polymer used in this work, to National Foundation for Science and Technology Development (CNPq) for the scholarships and profs. Dr. Daniel D. Melo (UFRN), Dr. Edson N. Ito (UFRN) and Dr. Luiz Fernando Meneses Carvalho (IFPI-Teresina) for their kind help.

\section{References}

1. Hoornweg, D., \& Bhada-Tata, P. (2012). What a waste: a global review of solid waste management. Washington: World Bank.

2. Thompson, R. C., Moore, C. J., vom Saal, F. S., \& Swan, S. H. (2009). Plastics, the environment and human health: current consensus and future trends. Philosophical Transactions of the Royal Society of London. Series B, Biological Sciences, 364(1526), 2153-2166. PMid:19528062. http://dx.doi. org/10.1098/rstb.2009.0053.

3. Davis, G., \& Song, J. H. (2006). Biodegradable packaging based on raw materials from crops and their impact on waste management. Industrial Crops and Products, 23(2), 147-161. http://dx.doi.org/10.1016/j.indcrop.2005.05.004.

4. Le Duigou, A., Pillin, I., Bourmaud, A., Davies, P., \& Baley, C. (2008). Effect of recycling on mechanical behaviour of biocompostable flax/poly(L-lactide) composites. Composites. Part A, Applied Science and Manufacturing, 39(9), 1471-1478. http://dx.doi.org/10.1016/j.compositesa.2008.05.008.

5. Pillin, I., Montrelay, N., Bourmaud, A., \& Grohens, Y. (2008). Effect of thermo-mechanical cycles on the physicochemical properties of poly(lactic acid). Polymer Degradation \& Stability, 93(2), 321-328. http://dx.doi.org/10.1016/j. polymdegradstab.2007.12.005.

6. Nishida, H., Fan, Y., Mori, T., Oyagi, N., Shirai, Y., \& Endo, T. (2005). Feedstock recycling of flame-resisting poly(lactic acid) aluminum hydroxide composite. Industrial \& Engineering Chemistry Research, 44(5), 1433-1437. http://dx.doi.org/10.1021/ ie049208+.

7. Sikorska, W., Richert, J., Rydz, J., Musioł, M., Adamus, G., Janeczek, H., \& Kowalczuk, M. (2012). Degradability studies of poly(L-lactide) after multi-reprocessing experiments in extruder. Polymer Degradation \& Stability, 97(10), 1891-1897. http://dx.doi.org/10.1016/j.polymdegradstab.2012.03.049.

8. Gurieff, N., \& Lant, P. (2007). Comparative life cycle assessment and financial analysis of mixed culture polyhydroxyalkanoate production. Bioresource Technology, 98(17), 3393-3403. PMid:17632000. http://dx.doi.org/10.1016/j.biortech.2006.10.046.

9. Shah, A. A., Kato, S., Shintani, N., Kamini, N. R., \& NakajimaKambe, T. (2014). Microbial degradation of aliphatic and aliphatic-aromatic co-polyesters. Applied Microbiology and Biotechnology, 98(8), 3437-3447. PMid:24522729. http:// dx.doi.org/10.1007/s00253-014-5558-1.

10. Coutinho, B. C., Miranda, G. B., Sampaio, G. R., Souza, L. B. S., Santana, W. J., \& Coutinho, H. D. M. (2004). A importância e as vantagens do polihidroxibutirato (plástico biodegradável). Holos, 20(3), 76-81. http://dx.doi.org/10.15628/holos.2004.49.

11. Sánchez, R. J., Schripsema, J., Silva, L. F., Taciro, M. K., Pradella, J. G. C., \& Gomez, J. G. C. (2003). Medium-chainlength Polyhydroxy-Alkanoic Acids (PHAMCL) produced by Pseudomonas Putida IPT 046 from renewable sources. 
European Polymer Journal, 39(7), 1385-1394. http://dx.doi. org/10.1016/S0014-3057(03)00019-3.

12. Doi, Y.(1990). Microbial polyesters. New York: VCH Publishers Inc.

13. Hablot, E., Bordes, P., Pollet, E., \& Averous, L. (2008). Thermal and thermo-mechanical degradation of poly(3hydroxybutyrate)-based multiphase systems. Polymer Degradation \& Stability, 93(2), 413-421. http://dx.doi. org/10.1016/j.polymdegradstab.2007.11.018.

14. Nguyen, S., Yu, G., \& Marchessault, R. (2002). Thermal degradation of poly(3-hydroxyalkanoates): preparation of well-defined oligomers. Biomacromolecules, 3(1), 219-224. PMid:11866577. http://dx.doi.org/10.1021/bm0156274.

15. Sadi, R. K. (2010). Compatibilization and degradation study of Polypropylene/Poly(3-hydroxybutyrate) (PP/PHB) blends (Doctoral thesis). Escola Politécnica, Universidade de São Paulo, São Paulo.

16. Melchiors, M., Keul, H., \& Höcker, H. (1996). Depolymerization of poly[(R)-3-hydroxybutyrate] to cyclic oligomers and polymerization of the cyclic trimer: an example of thermodynamic recycling. Macromolecules, 29(20), 6442-6451. http://dx.doi. org/10.1021/ma9604350

17. Yang, X., Clénet, J., Xu, H., Odelius, K., \& Hakkarainen, M. (2015). Two step extrusion process: from thermal recycling of PHB to plasticized PLA by reactive extrusion grafting of PHB degradation products onto PLA chains. Macromolecules, 48(8), 2509-2518. PMid:27053818. http://dx.doi.org/10.1021/ acs.macromol.5b00235.

18. Spekreijse, J., Le Nôtre, J., Sanders, J. P. M., \& Scott, E. L. (2015). Conversion of polyhydroxybutyrate (PHB) to methyl crotonate for the production of biobased monomers. Journal of Applied Polymer Science, 132(35), n/a. http://dx.doi. org/10.1002/app.42462.

19. Osanai, Y., Toshima, K., \& Matsumura, S. (2003). Enzymatic degradation of poly(R,S-3-hydroxybutanoate) to cyclic oligomers under continuous flow. Green Chemistry, 5(5), 567-570. http:// dx.doi.org/10.1039/B304640K.

20. Grassie, N., Murray, E. J., \& Holmes, P. A. (1984). The thermal degradation of poly(-(d)-b-hydroxybutyric acid): part 1 - Identification and quantitative analysis of products Polymer Degradation \& Stability, 6(1), 47-61. http://dx.doi. org/10.1016/0141-3910(84)90016-8.

21. Karlsson, S., Sares, C., Renstad, R., \& Albertsson, A. C. (1994). Gas chromatographic, liquid chromatographic and gas chromatographic-mass spectrometric identification of degradation products in accelerated aged microbial polyhydroxyalkanoates. Journal of Chromatography. A, 669(1-2), 97-102. PMid:8075778. http://dx.doi.org/10.1016/0021-9673(94)80341-2.

22. Yu, P. H., Chua, H., Huang, A. L., Lo, W., \& Chen, G. Q. (1998). Conversion of food industrial wastes into bioplastics. Applied Biochemistry and Biotechnology, 70-72(1), 603-614. PMid:18576025. http://dx.doi.org/10.1007/BF02920172.

23. King, P. P. (1982). Biotechnology. An industrial view. Journal of Chemical Technology and Biotechnology (Oxford, Oxfordshire), 32(1), 2-8. http://dx.doi.org/10.1002/jctb.5030320103.

24. Rosa, D. S., \& Pântano, R., Fo. (2003). Biodegradação: um ensaio com polímeros. Itatiba: Moara.

25. Foster, L. J. R., \& Tighe, B. J. (2005). Centrifugally spun polyhydroxybutyrate fibres: accelerated hydrolytic degradation studies. Polymer Degradation \& Stability, 87(1), 1-10. http:// dx.doi.org/10.1016/j.polymdegradstab.2003.11.012.

26. Ariffin, H., Nishida, H., Shirai, Y., \& Hassan, M. A. (2010). Highly selective transformation of poly[(R)-3-hydroxybutyric acid] into trans-crotonic acid by catalytic thermal degradation. Polymer Degradation \& Stability, 95(8), 1375-1381. http:// dx.doi.org/10.1016/j.polymdegradstab.2010.01.018.

27. Kim, K. J., Doi, Y., \& Abe, H. (2008). Effect of metal compounds on thermal degradation behavior of aliphatic poly(hydroxyalkanoic acid)s. Polymer Degradation \& Stability, 93(4), 776-785. http:// dx.doi.org/10.1016/j.polymdegradstab.2008.01.026.

28. Farid, N. F. S. M., Ariffin, H., Mamat, M. R. Z., Mohd Zahari, M. A. K., \& Hassan, M. A. (2015). Non-solvent-based pretreatment of poly(3-hydroxybutyrate) for improved bio-based crotonic acid production. RSC Advances, 5(42), 33546-33553. http:// dx.doi.org/10.1039/C5RA03017J.

29. Ariffin, H., Nishida, H., Shirai, Y., \& Hassan, M. A. (2008). Determination of multiple thermal degradation mechanisms of poly(3-hydroxybutyrate). Polymer Degradation \& Stability, 93(8), 1433-1439. http://dx.doi.org/10.1016/j. polymdegradstab.2008.05.020.

30. Kopinke, F. D., Remmler, M., \& Mackenzie, K. (1996). Thermal decomposition of biodegradable polyesters-I: Poly $(\beta-$ hydroxybutyric acid). Polymer Degradation \& Stability, 52 (1), 25-38. http://dx.doi.org/10.1016/0141-3910(95)00221-9.

31. Aoyagi, Y., Yamashita, K., \& Doi, Y. (2002). Thermal degradation of poly[(R)-3-hydroxybutyrate], poly[E-caprolactone], and poly [(S)-lactide]. Polymer Degradation \& Stability, 76(1), 53-59. http://dx.doi.org/10.1016/S0141-3910(01)00265-8.

32. Hong, S. G., Lin, Y. C., \& Lin, C. H. (2008). Crystallization and degradation behaviors of treated polyhydroxybutyrates. Reactive \& Functional Polymers, 68(11), 1516-1523. http:// dx.doi.org/10.1016/j.reactfunctpolym.2008.08.003.

33. Kawalec, M., Adamus, G. Y., Kurcok, P., Kowalczuk, M., Foltran, I., Focarete, M. L., \& Scandola, M. (2007). Carboxylate-induced degradation of poly(3-hydroxybutyrate)s. Biomacromolecules, 8(4), 1053-1058. PMid:17330956. http://dx.doi.org/10.1021/ bm061155n.

34. Galego, N., \& Rozsa, C. (1999). Thermal decomposition of some poly(b-hydroxyalcanoates). Polymer International, 48(12), 1202-1204. http://dx.doi.org/10.1002/(SICI)10970126(199912)48:12<1202::AID-PI223>3.0.CO;2-D.

35. Lehrle, R., Williams, R., French, C., \& Hammond, T. (1995). Thermolysis and methanolysis of poly(b-hydroxybutyrate): random scission assessed by statistical analysis of molecular weight distributions. Macromolecules, 28(13), 4408-4414. http://dx.doi.org/10.1021/ma00117a008.

36. Bahari, K., Mitomo, H., Enjoji, T., Yoshii, F., \& Makuuchi, K. (1998). Degradability of poly(3-hydroxybutyrate) and its copolymer grafted with styrene by radiation. Polymer Degradation \& Stability, 61(2), 245-252. http://dx.doi.org/10.1016/S01413910(97)00147-X.

37. Lee, H. K., Ismail, J., Kammer, H. W., \& Bakar, M. A. (2005). Melt reaction in blends of poly(3-hydroxybutyrate) (PHB) and epoxidized natural rubber (ENR-50). Journal of Applied Polymer Science, 95(1), 113-129. http://dx.doi.org/10.1002/ app. 20808

38. Hong, S. G., Gau, T. K., \& Huang, S. C. (2011). Enhancement of the crystallization and thermal stability of polyhydroxybutyrate by polymeric additives. Journal of Thermal Analysis and Calorimetry, 103(3), 967-975. http://dx.doi.org/10.1007/ s10973-010-1180-3.

39. Morikawa, H., \& Marchessault, R. H. (1981). Pyrolysis of bacterial polyalkanoates. Canadian Journal of Chemistry, 59(15), 2306-2313. http://dx.doi.org/10.1139/v81-334.

40. Ballistreri, A., Garozzo, D., Giuffrida, M., Impallomeni, G., \& Montaudo, G. (1989). Analytical degradation: an approach to the structural analysis of microbial polyesters by different methods. Journal of Analytical and Applied Pyrolysis, 16(3), 239-253. http://dx.doi.org/10.1016/0165-2370(89)80028-2.

41. Rosa, D. S., Calil, M. R., Guedes, C. G. F., \& Santos, C. E. O. (2001). The Effect of UV-B Irradiation on the biodegradability of poly- $\beta$-hydroxybutyrate (PHB) and poly- $\varepsilon$-caprolactone (PCL). Journal of Polymers and the Environment, 9(3), 109113. http://dx.doi.org/10.1023/A:1020498710586.

42. Kopinke, F. D., \& Mackenzie, K. (1997). Mechanistic aspects of the thermal degradation of poly(lactic acid) and 
poly(beta-hydroxybutyric acid). Journal of Analytical and Applied Pyrolysis, 40-41, 43-53. http://dx.doi.org/10.1016/ S0165-2370(97)00022-3.

43. Barham, P. J., Keller, A., Otun, E. L., \& Holmes, P. A. (1984). Crystallization and morphology of a bacterial thermoplastic: poly-3-hydroxybutyrate. Journal of Materials Science, 19(9), 2781-2794. http://dx.doi.org/10.1007/BF01026954.

44. Srubar, W. V., 3rd, Wright, Z. C., Tsui, A., Michel, A. T., Billington, S. L., \& Frank, C. W. (2012). Characterizing the effects of ambient aging on the mechanical and physical properties of two commercially available bacterial thermoplastics. Polymer Degradation \& Stability, 97(10), 1922-1929. http:// dx.doi.org/10.1016/j.polymdegradstab.2012.04.011.

45. Coutinho, F. M. B., Mello, I. L., \& Santa Maria, L. C. (2003). Polietileno: principais tipos, propriedades e aplicações. Polímeros. Ciência e Tecnologia, 13(1), 1-13. http://dx.doi. org/10.1590/S0104-14282003000100005.

46. El-Hadi, A., Schnabel, R., Straube, E., Müller, G., \& Henning, S. (2002). Correlation between degree of crystallinity, morphology, glass temperature, mechanical properties and biodegradation of poly (3-hydroxyalkanoate) PHAs and their blends. Polymer Testing, 21(6), 665-674. http://dx.doi.org/10.1016/S01429418(01)00142-8.

47. Sadi, R. K., Fechine, G. J. M., \& Demarquette, N. R. (2010). Photodegradation of poly(3-hydroxybutyrate). Polymer Degradation \& Stability, 95(12), 2318-2327. http://dx.doi. org/10.1016/j.polymdegradstab.2010.09.003.

48. Rabello, M. S., \& White, J. R. (1997). Crystallization and melting behavior of photodegraded polypropylene - I. Chemicrystallization. Polymer, 38(26), 6379-6387. http://dx.doi. org/10.1016/S0032-3861(97)00213-9.

49. Renstad, R., Karlsson, S., \& Albertsson, A. C. (1997). Influence of processing parameters on the molecular weight and mechanical properties of poly(3-hydroxybutyrate-3-hydroxyvalerate). Polymer Degradation \& Stability, 57(3), 331-338. http://dx.doi. org/10.1016/S0141-3910(97)00028-1.

50. Kendall, A. (2012). A life cycle assessment of biopolymer production from material recovery facility residuals. Resources, Conservation and Recycling, 61, 69-74. http://dx.doi.org/10.1016/j. resconrec.2012.01.008.

51. Currann, M. A. (1996). Environmental life-cycle assessment. New York: McGraw Hill.

52. Feller, J. F., \& Bourmaud, A. (2003). Rheological and calorimetric properties of recycled bisphenol A poly(carbonate). Polymer Degradation \& Stability, 82(1), 99-104. http://dx.doi. org/10.1016/S0141-3910(03)00169-1.

53. Spinace, M. A. S., \& De Paoli, M. A. (2004). Nonisothermal crystallization of reprocessed poly(ethylene terephthalate). Journal of Applied Polymer Science, 91(1), 525-531. http:// dx.doi.org/10.1002/app.13230.

54. Javierre, C., Claveria, I., Ponz, L., Aisa, J., \& Fernandez, A. (2007). Influence of the recycled material percentage on the rheological behaviour of HDPE for injection moulding process. Waste Management (New York, N.Y.), 27(5), 656-663. PMid:16707257. http://dx.doi.org/10.1016/j.wasman.2006.03.005.

55. Santos, A. S. F., Agnelli, J. A. M., Trevisan, D. W., \& Manrich, S. (2002). Degradation and stabilization of polyolefins from municipal plastic waste during multiple extrusions under different reprocessing conditions. Polymer Degradation \& Stability, 77(3), 441-447. http://dx.doi.org/10.1016/S01413910(02)00101-5.
56. Hamzehlou, S. H., \& Katbab, A. A. (2007). Bottle-to-bottle recycling of PET via nanostructure formation by melt intercalation in twin screw compounder: improved thermal, barrier, and microbiological properties. Journal of Applied Polymer Science, 106(2), 1375-1382. http://dx.doi.org/10.1002/ app.26730.

57. Abad, M. J., Ares, A., Barral, L., Cano, J., Díez, F. J., GarcíaGarabal, S., López, J., \& Ramírez, C. (2004). Effects of a mixture of stabilizers on the structure and mechanical properties of polyethylene during reprocessing. Journal of Applied Polymer Science, 92(6), 3910-3916. http://dx.doi.org/10.1002/app.20420.

58. Chen, C., Fei, B., Peng, S., Zhuang, Y., Dong, L., \& Feng, Z. (2002). The Kinetics of the Thermal Decomposition of Poly(3hydroxybutyrate) and Maleated Poly(3-hydroxybutyrate). Journal of Applied Polymer Science, 84(9), 1789-1796. http:// dx.doi.org/10.1002/app.10463.

59. Koning, G. J. M., Lemstra, P. J., Hill, D. J. T., Carswell, T. G., \& O'Donnell, J. H. (1992). Ageing phenomena in bacterial poly[(R)-3-hydroxybutyrate] I. A study on the mobility in poly [(R)-3-hydroxybutyrate] powders by monitoring the radical decay with temperature after radiolysis at 77 K. Polymer, 33(15), 3295-3297. http://dx.doi.org/10.1016/0032-3861(92)90250-Z.

60. Koning, G. J. M., \& Lemstra, P. J. (1993). Crystallization phenomena in bacterial poly[(R)-3- hydroxybutyrate]: 2 . Embrittlement and rejuvenation. Polymer, 34(19), 4089-4094. http://dx.doi.org/10.1016/0032-3861(93)90671-V.

61. Ong, Y. T., Ahmad, A. L., Zein, S. H. S., Sudesh, K., \& Tan, S. H. (2011). Poly(3-hydroxybutyrate)-functionalised multiwalled carbon nanotubes/chitosan green nanocomposite membranes and their application in pervaporation. Separation and Purification Technology, 76(3), 419-427. http://dx.doi. org/10.1016/j.seppur.2010.11.013.

62. Gonzalez, A., Irusta, L., Fernández-Berridi, M. J., Iriarte, M., \& Iruin, J. J. (2005). Application of pyrolysis/gas chromatography/ Fourier transform infrared spectroscopy and TGA techniques in the study of thermal degradation of poly (3-hydroxybutyrate). Polymer Degradation \& Stability, 87(2), 347-354. http://dx.doi. org/10.1016/j.polymdegradstab.2004.09.005

63. Vogel, C., Morita, S., Sato, H., Noda, I., Ozaki, Y., \& Siesler, H. W. (2007). Thermal Degradation of Poly(3-hydroxybutyrate) and Poly(3-hydroxybutyrate-co-3-hydroxyhexanoate) in Nitrogen and Oxygen Studied by Thermogravimetric-Fourier Transform Infrared Spectroscopy. Applied Spectroscopy, 61(7), 755-764. PMid:17697470. http://dx.doi.org/10.1366/000370 207781393370

64. Yu, J., Plackett, D., \& Chen, L. X. L. (2005). Kinetics and mechanism of the monomeric products from abiotic hydrolysis of poly[(R)-3-hydroxybutyrate] under acidic and alkaline conditions. Polymer Degradation \& Stability, 89(2), 289-299. http://dx.doi.org/10.1016/j.polymdegradstab.2004.12.026.

65. Bhargava, R., \& Levi, I. W. (Ed.). (2005). Spectrochemical analysis using infrared multichannel detectors. Oxford: Blackwell Publishing. http://dx.doi.org/10.1002/9780470988541.

66. Hoffmann, R. (1970). The norcaradiene cicloheptatriene equilibrium. Tetrahedron Letters, 11(33), 2907-2909. http:// dx.doi.org/10.1016/S0040-4039(01)98370-4.

Received: Dec. 11, 2015

Revised: May 23, 2016 Accepted: June 29, 2016 